\title{
Long-term effects of mixed planting on arbuscular mycorrhizal fungal communities in the roots and soils of Juglans mandshurica plantations
}

\author{
Li Ji ${ }^{1,2}$, Yan Zhang ${ }^{1}$, Yuchun Yang ${ }^{2}$, Lixue Yang ${ }^{1 *}$, Na Yang ${ }^{1,3}$ and Depeng Zhang ${ }^{1}$
}

\begin{abstract}
Background: Establishing mixed plantations is an effective way to improve soil fertility and increase forest productivity. Arbuscular mycorrhizal (AM) fungi are obligate symbiotic fungi that can promote mineral nutrient absorption and regulate intraspecific and interspecific competition in plants. However, the effects of mixed plantations on the community structure and abundance of AM fungi are still unclear. Illumina MiSeq sequencing was used to investigate the AM fungal community in the roots and soils of pure and mixed plantations (Juglans mandshurica $\times$ Larix gmelinii). The objective of this study is to compare the differential responses of the root and rhizosphere soil AM fungal communities of Juglans mandshurica to long-term mixed plantation management.
\end{abstract}

Results: Glomus and Paraglomus were the dominant genera in the root samples, accounting for more than $80 \%$ of the sequences. Compared with that in the pure plantation, the relative abundance of Glomus was higher in the mixed plantation. Glomus, Diversispora and Paraglomus accounted for more than $85 \%$ of the sequences in the soil samples. The relative abundances of Diversispora and an unidentified genus of Glomeromycetes were higher and lower in the pure plantation, respectively. The Root_P samples (the roots in the pure plantation) had the highest number of unique OTUs (operational taxonomic units), which belonged mainly to an unidentified genus of Glomeromycetes, Paraglomus, Glomus and Acaulospora. The number of unique OTUs detected in the soil was lower than that in the roots. In both the root and soil samples, the forest type did not have a significant effect on AM fungal diversity, but the Sobs value and the Shannon, Chao1 and Ace indices of AM fungi in the roots were significantly higher than those in the soil.

Conclusions: Mixed forest management had little effect on the AM fungal community of Juglans mandshurica roots and significantly changed the community composition of the soil AM fungi, but not the diversity.

Keywords: Mixed plantation, Arbuscular mycorrhizal fungi, Juglans mandshurica, Larix gmelinii, Illumina MiSeq sequencing

\footnotetext{
*Correspondence: ylx_0813@163.com

${ }^{1}$ Key Laboratory of Sustainable Forest Ecosystem Management-Ministry of

Education, School of Forestry, Northeast Forestry University, Harbin 150040, P.

R. China

Full list of author information is available at the end of the article
}

C C The Author(s). 2020 Open Access This article is licensed under a Creative Commons Attribution 4.0 International License, which permits use, sharing, adaptation, distribution and reproduction in any medium or format, as long as you give appropriate credit to the original author(s) and the source, provide a link to the Creative Commons licence, and indicate if changes were made. The images or other third party material in this article are included in the article's Creative Commons licence, unless indicated otherwise in a credit line to the material. If material is not included in the article's Creative Commons licence and your intended use is not permitted by statutory regulation or exceeds the permitted use, you will need to obtain permission directly from the copyright holder. To view a copy of this licence, visit http://creativecommons.org/licenses/by/4.0/. The Creative Commons Public Domain Dedication waiver (http://creativecommons.org/publicdomain/zero/1.0/) applies to the data made available in this article, unless otherwise stated in a credit line to the data. 


\section{Background}

Arbuscular mycorrhizal (AM) fungi are widespread and form symbiotic associations with approximately $80 \%$ of terrestrial plant species [1]. AM fungi not only promote absorption of mineral nutrients $(\mathrm{C}, \mathrm{N}, \mathrm{P})[2-4]$, provide resistance to environmental stress $[5,6]$ and regulate intraspecific and interspecific competition in plants [7] but also directly and indirectly improve soil structure and affect the circulation of matter and flows of energy in the ecosystem [8]. Some studies have found that host plants preferentially allocate carbohydrates to the more beneficial symbionts when providing photosynthetic products to AM fungi [9-11]; this preference/selection results in varying AM community richness, composition and diversity, which induces the unequal effects of AM fungi on the growth rates of different plant species [12].

Previous studies have indicated that AM fungal taxonomic groups differ in terms of the main propagule form with which they colonize new roots and the allocation of biomass to the compartments of roots and soil [13]. To a certain extent, the composition and community structure of AM fungi depends on their propagation form (spores, infected root segments, extensive extraradical mycelium), and the difference between the propagation of AM fungi in root (intraradical) and soil (extraradical) samples may be related to the location and density of AM fungal propagules [14]. In addition, host plant selection for AM fungi exhibited strong selection pressure for AM fungi in the root system [15]. Moreover, the response of different AM fungal groups to host plants or the rhizosphere microenvironment may also lead to host plant selection preferences for certain AM fungal species [16]. There are differences in the distribution patterns of root carbon and the pathways to secondary metabolites or secretions, and these differences may cause changes in soil environmental conditions $[9,17]$. A recent study found that AM fungal structures in roots and soil have different responses to biotic and abiotic factors. The AM fungal community structure in roots is mainly affected by host plants and disturbances (grazing), while AM fungi in soil are greatly affected by environmental factors [18].

AM fungi can form a huge mycorrhizal network and connect individual plants within the community, which facilitates the transport of nutrient resources among plants [19]. Therefore, neighboring plants can affect the impact of host plants on AM fungi or form specific AM fungal communities when multiple plants are planted in combination in terrestrial ecosystems $[12,20]$. Previous studies have found that the construction of AM fungal communities is influenced by the identity of adjacent plants, and these studies have mostly occurred in greenhouses and invasive systems [21]. However, it is not clear how the coexistence of multiple plants affects arbuscular mycorrhizal fungal communities in natural ecosystems, especially in forest ecosystems.

Forests play important roles in producing wood and fuel, controlling soil erosion and maintaining ecosystem functions [22]. Monocultures account for $80 \%$ of the total forest planting area in China. Establishing and managing a monoculture are easier than doing the same for a mixed plantation, but it will reduce the ecological function of the forest, and long-term monoculture planting will cause litter quality and soil fertility to decline as well as causing other problems (e.g., biodiversity loss, soil degradation) [23]. Mixed plantations are an effective way to improve soil fertility and increase forest productivity [22, 24]. Numerous studies have shown that rational mixed plantations can improve soil fertility [25], nutrient cycling [25], stand productivity [26, 27], and tree nutrient status and resistance to pests and diseases [28]. However, the effects of mixed planting vary among tree species [29, 30]. Therefore, comparing the differences in AM fungal communities in different plantation types is conducive to developing a profound understanding of the stimulation mechanism by which mixed plantations influence AM fungal communities.

Larix gmelinii (an ectomycorrhizal species) is a major fast-growing afforestation species in northern China [31]. L. gmelinii plantations have long had certain problems, such as biodiversity loss and soil degradation with the rapid development of larch monocultures [32], that seriously affect their sustainable management. Juglans mandshurica (an arbuscular mycorrhizal species) is an important timber tree species in northeastern China and has great economic value. It has been reported that the mixed management of Juglans mandshurica and Larix gmelinii can improve soil fertility and stand productivity [33]; however, until now, the synergistic mechanism of mixed management, especially the interactions between the host plants and the soil AM fungal community structure, is still obscure. For this purpose, we compared the AM fungal community composition, structure and diversity in the roots and soil of Juglans mandshurica in pure and mixed plantations to provide a theoretical basis for the mechanism by which temperate mixed plantations influence AM fungal communities. We hypothesized that (1) mixed forests have a significant effect on the AM fungal community structure and composition in the roots and soil of Juglans mandshurica and that there will be higher AM fungal diversity and richness in the mixed plantation than in the pure plantation and (2) in both forest types, the diversity and richness of $\mathrm{AM}$ fungi in the soil will be higher than those in the roots. 


\section{Results}

\section{Soil properties and AM fungal colonization}

The soil $\mathrm{pH}$ and total phenol content were significantly higher in the pure plantation than in the mixed plantation (Table $1 ; P<0.05$ ). The $\mathrm{NH}_{4}{ }^{+}-\mathrm{N}$ content was significantly higher in the mixed plantation than in the pure plantation. Compared with those in the mixed plantation, the soil moisture, $\mathrm{P}, \mathrm{C} / \mathrm{N}$ ratio, $\mathrm{N}_{\text {mic }}, \mathrm{CPh}$, WSPh and colonization were mainly lower in the pure plantation, although no significant differences were found $(P>0.05)$.

\section{Sequence summary}

Across all soil and root samples analyzed, 190,433 quality AM fungal sequences were yielded by Illumina MiSeq sequencing, with 11,388 19,701 AM fungal sequences per sample (mean $=15,869$ ). The average read lengths were $238 \mathrm{bp}$ for the $18 \mathrm{~S}$ rRNA gene regions and higher than $99 \%$ of Good's coverage for the $18 \mathrm{~S}$ rRNA gene regions. For all samples, five orders, nine families, ten genera and one hundred and thirty-nine OTUs were detected. The rarefaction curves of OTUs tended to approach the saturation plateau at $97 \%$ sequence similarity for all samples (Supplementary Figure S1), which indicated that the sequencing depth was adequate for assessing the diversity of the AM fungal communities in all samples.

\section{AM fungal community composition}

Across all root samples, nine AM fungal genera were detected. Glomus and Paraglomus were the dominant genera, accounting for more than $80 \%$ of the sequences

Table 1 Soil variables and AM fungal colonization in pure and mixed plantations

\begin{tabular}{|c|c|c|}
\hline Environmental variables & Pure plantation & Mixed plantation \\
\hline $\mathrm{pH}$ & $5.89 \pm 0.06 a$ & $5.63 \pm 0.04 b$ \\
\hline Moisture (\%) & $84.60 \pm 2.23 a$ & $91.83 \pm 10.59 a$ \\
\hline$C\left(\mathrm{~g} \cdot \mathrm{kg}^{-1}\right)$ & $105.97 \pm 10.12 \mathrm{a}$ & $105.02 \pm 20.26 a$ \\
\hline$N\left(g \cdot \mathrm{kg}^{-1}\right)$ & $9.36 \pm 0.8 a$ & $9.07 \pm 1.72 \mathrm{a}$ \\
\hline$P\left(g \cdot \mathrm{kg}^{-1}\right)$ & $1.24 \pm 0.07 a$ & $1.29 \pm 0.16 a$ \\
\hline $\mathrm{C} / \mathrm{N}$ & $11.31 \pm 0.16 \mathrm{a}$ & $11.56 \pm 0.06 a$ \\
\hline$C_{\text {mic }}\left(\mathrm{mg} \cdot \mathrm{kg}^{-1}\right)$ & $2299.94 \pm 142.23 a$ & $1590.32 \pm 372.04 a$ \\
\hline $\mathrm{N}_{\text {mic }}\left(\mathrm{mg} \cdot \mathrm{kg}^{-1}\right)$ & $351.32 \pm 21.99 a$ & $402.67 \pm 16.29 a$ \\
\hline $\mathrm{NH}_{4}^{+}-\mathrm{N}\left(\mathrm{mg} \cdot \mathrm{kg}^{-1}\right)$ & $6.01 \pm 0.28 b$ & $8.20 \pm 0.57 a$ \\
\hline $\mathrm{NO}_{3}{ }^{-}-\mathrm{N}\left(\mathrm{mg} \cdot \mathrm{kg}^{-1}\right)$ & $31.73 \pm 1.23 a$ & $28.62 \pm 2.37 a$ \\
\hline TPh $\left(\mathrm{mg} \cdot \mathrm{kg}^{-1}\right)$ & $690.17 \pm 8.54 a$ & $536.37 \pm 37.86 b$ \\
\hline $\mathrm{CPh}\left(\mathrm{mg} \cdot \mathrm{kg}^{-1}\right)$ & $188.21 \pm 6.93 a$ & $230.47 \pm 13.81 a$ \\
\hline WSPh $\left(\mathrm{mg} \cdot \mathrm{kg}^{-1}\right)$ & $4.37 \pm 0.19 a$ & $4.63 \pm 0.33 a$ \\
\hline Colonization (\%) & $95.56 \pm 2.94 a$ & $96.70 \pm 2.41 \mathrm{a}$ \\
\hline
\end{tabular}

$C_{\text {mic }}$ soil microbial biomass carbon, $N_{\text {mic }}$ soil microbial biomass nitrogen, TPh soil total phenol, CPh soil complex phenol, WSPh soil water-souble phenol
(Fig. 1a). Compared with that in the pure plantation, the relative abundance of Glomus in root samples was higher in the mixed plantation (Fig. 1a). Across all soil samples, ten AM fungal genera were detected. Glomus, Diversispora and Paraglomus accounted for more than $85 \%$ of the sequences (Fig. 1b). The relative abundances of Diversispora and an unidentified genus of Glomeromycetes were higher and lower in the pure plantation, respectively. At the OTU level, 178 AM fungal taxa were detected. OTU79 and OTU76 were the dominant OTUs and had mean relative abundances of 12.15 and $6.54 \%$, respectively (Supplementary Table S2, Fig. 2).

\section{AM fungal community structure and diversity}

The number of Sobs and the Shannon, Chaol, Ace and Faith PD indices of the root samples were higher in the pure plantation (Fig. 3a-f; $P>0.05$ ), while the Sobs, Shannon, Chaol and Faith PD indices of the soil samples were higher in the mixed plantation $(P>$ 0.05). The Simpson index of the soil samples was significantly higher in the pure plantation than in the mixed plantation $(P<0.05)$. In the same type of sample (root or soil), the forest type did not have a significant effect on AM fungal diversity, but the Sobs, Shannon, Chao1 and Ace indices of AM fungi in the roots were significantly higher than those in the soil $(P<0.05)$.

Principal coordinates analysis ( $\mathrm{PCoA})$ analysis at the OTU level showed that the samples from Root_P, Root M, Soil_P and Soil_M were separated from each other (Fig. 4a). The two principal component axes explained more than $50 \%$ of the total variation (PCoA $1=33.07 \%$, PCoA $2=17.17 \%$ ). The analysis of similarities (ANOSIM) and permutation multivariate analysis of variance (PERMANOVA) demonstrated that the AM fungal community structure differed by sample type $(P=0.002)$ (Fig. 4b, Table S3).

\section{Shared and unique OTUs}

The Venn diagram analysis showed that all samples shared 22 OTUs, which accounted for $7.86 \%$ of the total OTUs observed (Fig. 5). At the genus level, these shared OTUs mainly belonged to Glomus, Paraglomus and Diversispora (Table S4). Samples from Root_P had the highest number of unique OTUs, which mainly belonged to the unidentified genus of Glomeromycetes, Paraglomus, Glomus and Acaulospora (Table S5). The amount of unique OTUs detected in the soil was lower than those in the roots. At the genus level, Soil_P had a significantly higher relative abundance of Diversispora than the other treatments (Fig. $6, P<0.05$ ). 

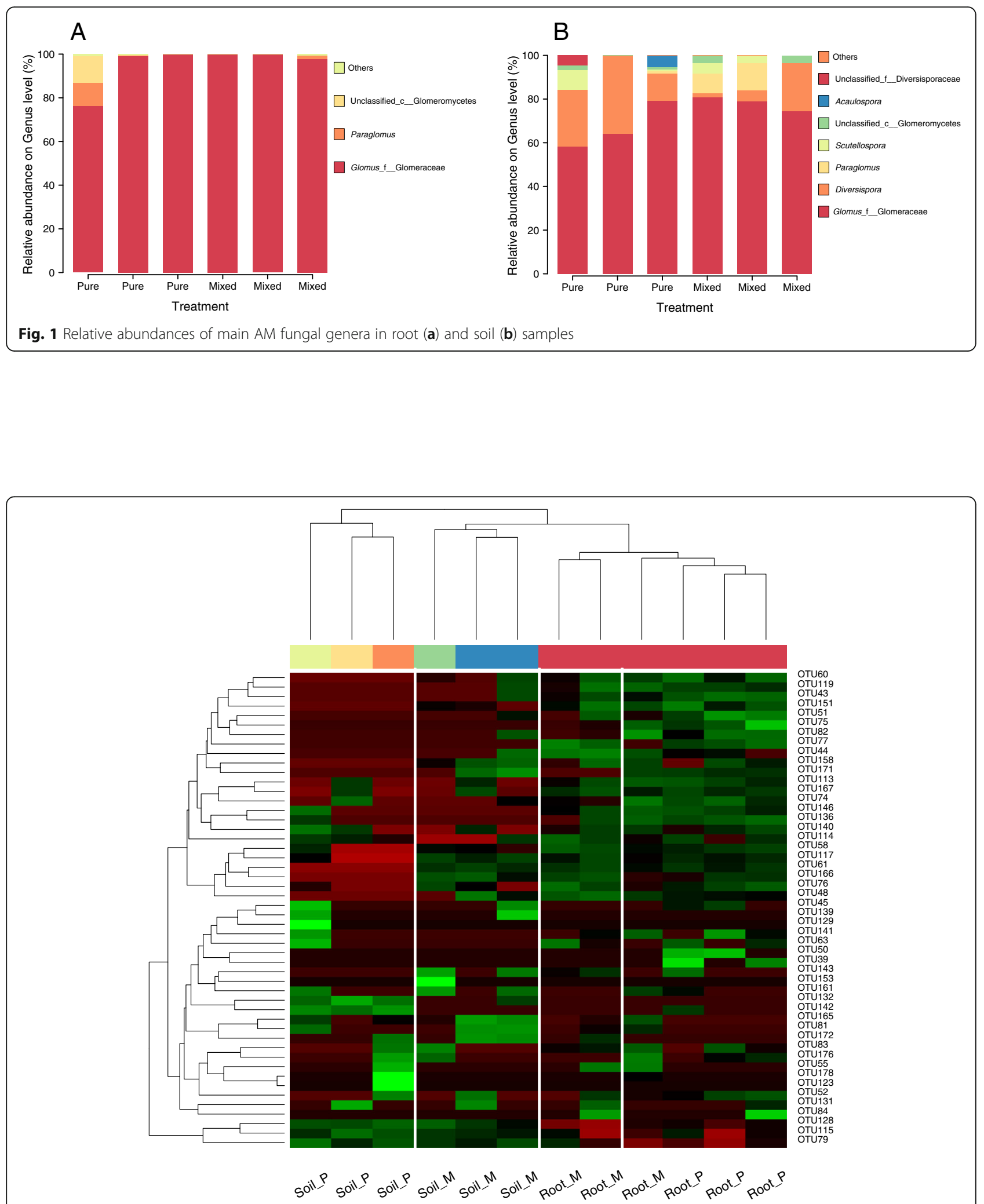

Fig. 2 Heat map analyses of AM fungal communities in the root and soil samples. The relative abundances of the top 50 most abundant classified AM fungal OTUs were identified in each sample by colors deduced from the raw Z-scores. Hierarchical clustering of all samples was performed using average clustering method with the Euclidean distances. Soil_P represents soil sample in pure plantation; Soil_M represents soil sample in mixed plantation; Root_P represents root sample in pure plantation; Root_M represents root sample in mixed plantation 

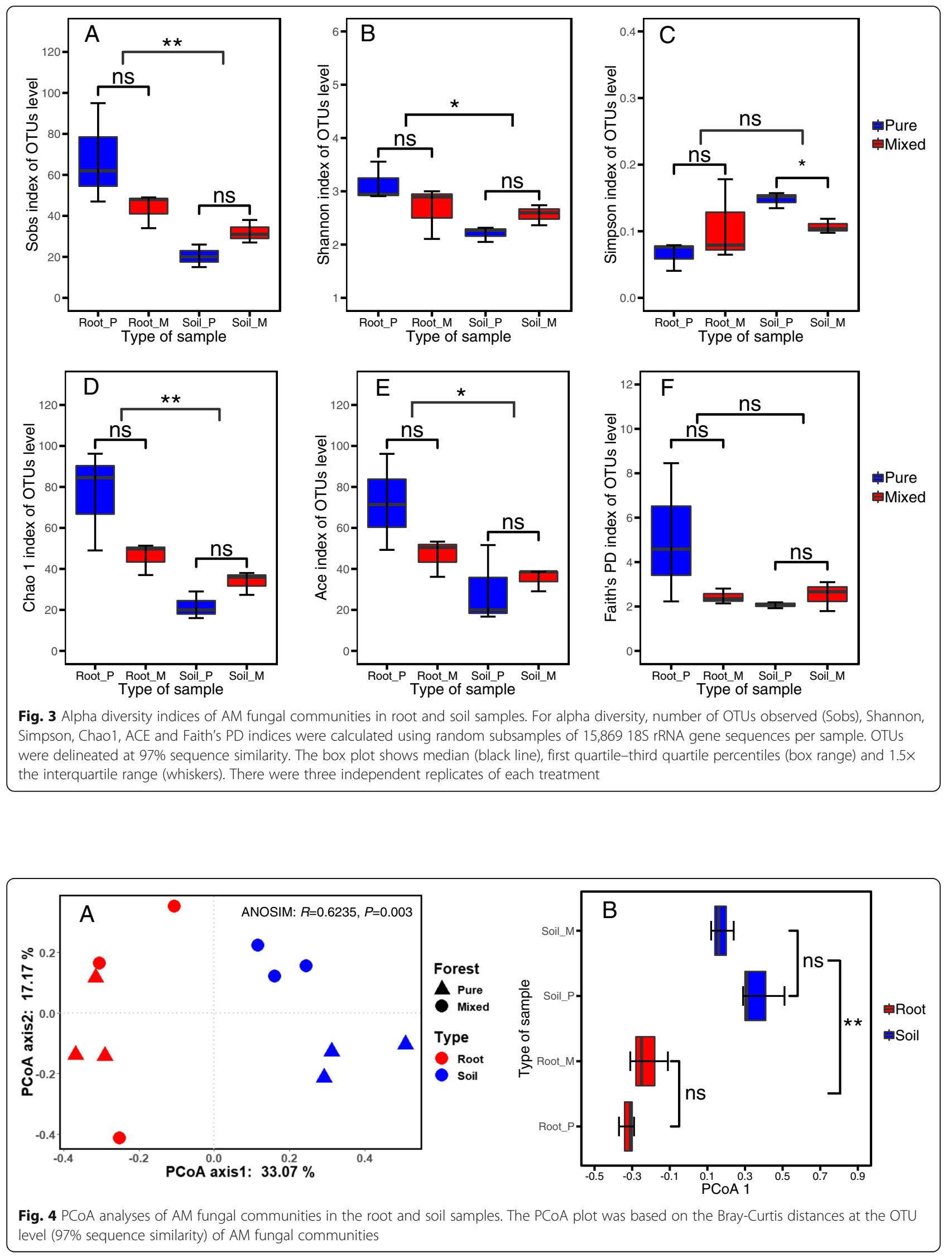


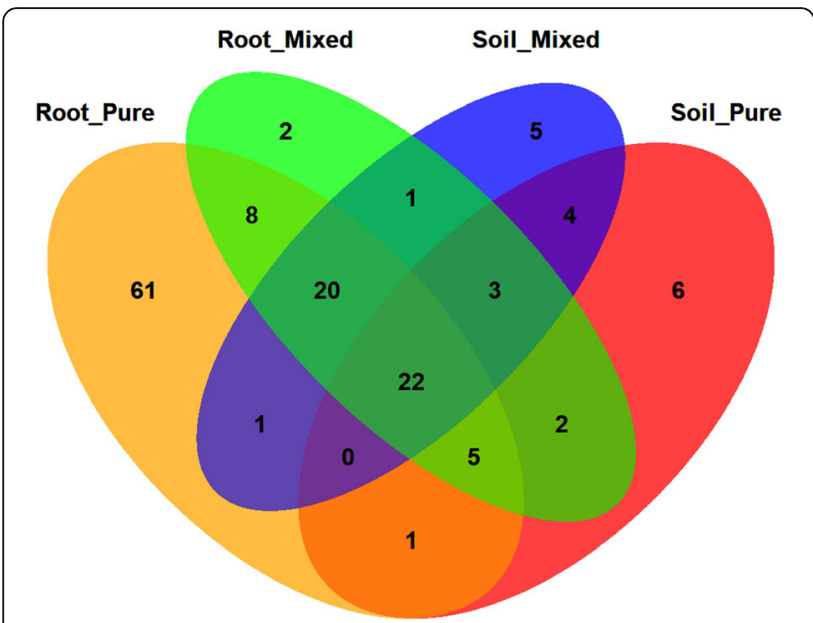

Fig. 5 Venn diagram analyses of AM fungal communities in the root and soil samples. Venn diagram demonstrated the numbers of shared and unique observed OTUs at 97\% similarity among treatments

\section{Relationships between AM fungal communities and soil characteristics}

RDA and the Mantel test were conducted to identify the key drivers of AM fungal community structure. In the RDA plots of the $\mathrm{AM}$ fungal community structure in both plantations, soil $\mathrm{NO}_{3}{ }^{-}-\mathrm{N}, \mathrm{C}_{\text {mic }}$ and $\mathrm{pH}$ appeared to be the most important soil characteristics controlling the root AM fungal community structure and showed major differences among microbial communities (Fig. 7a). The Mantel test demonstrated that root AM fungal abundance was significantly correlated with $\mathrm{NO}_{3}{ }^{-} \mathrm{N}\left(R^{2}=0.906, P=\right.$ $0.029)$ and $\mathrm{C}_{\text {mic }}\left(R^{2}=0.881, P=0.044\right)$ (Table 2). The soil complex phenols ( $\mathrm{CPh}), \mathrm{C} / \mathrm{N}, \mathrm{pH}, \mathrm{NO}_{3}{ }^{-}-\mathrm{N}$ and $\mathrm{NH}_{4}{ }^{+}-\mathrm{N}$ had longer arrows than the others (Fig. 7b). This indicates that these variables have stronger impacts than others on the AM fungal community. Of all the soil characteristics tested, $\mathrm{C} / \mathrm{N}\left(R^{2}=0.864\right.$, $P=0.032)$ and $\mathrm{CPh}\left(R^{2}=0.994, P=0.019\right)$ were significantly correlated with the relative abundance of OTUs (Table 2).

\section{Discussion}

Response of AM fungal diversity, composition and community structure to mixed planting

The core species composition of AM fungal communities was very similar and conservative between the pure and mixed plantations (Glomus mainly, Fig. 1), which is consistent with the result of Senés-Guerrero and Schüßler [34]. They found that there is a conservative core species of AM fungi both at different stages of plant development and under different environmental conditions in Andean ecosystems. Plant diversity has been shown to increase with increasing mycorrhizal fungal diversity, and the diversity and species composition of plant communities also exert a reciprocal influence on their associated mycorrhizal communities [15]. Van der Heijden et al. [35] believed that the change in host plants caused by colonization with a single mycorrhizal species was an important factor determining the species composition and diversity of plant communities. However, some researchers have reported that there is a negative correlation between plant diversity and AM fungal community diversity [36]. The lower diversity of AM fungi in the

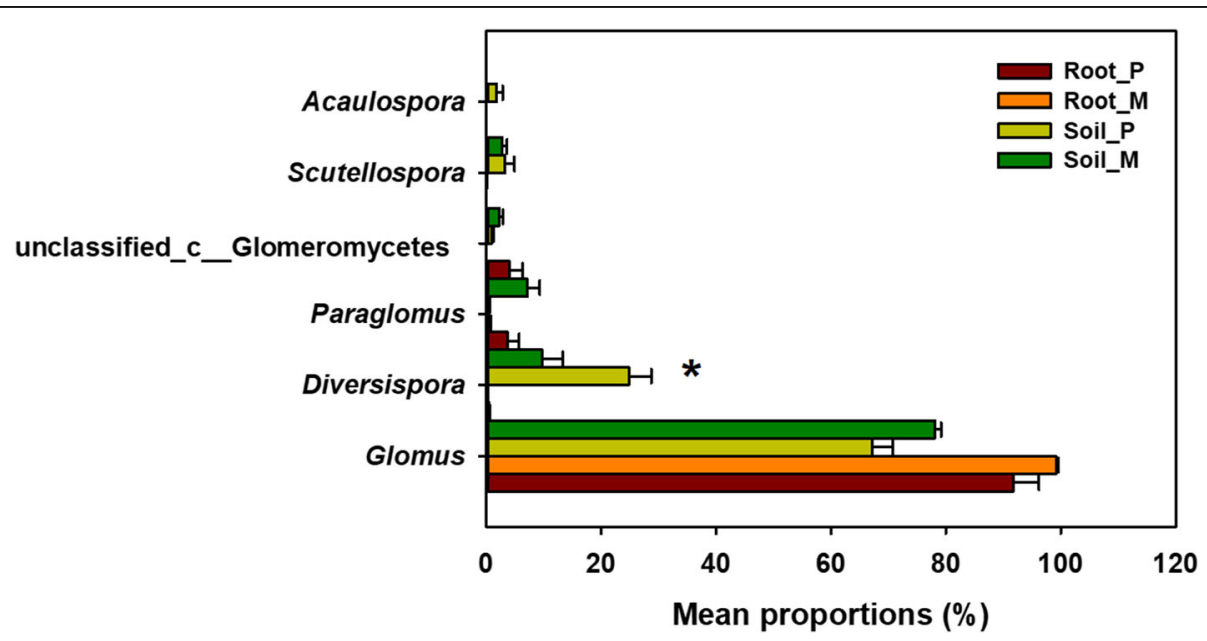

Fig. 6 Relative abundances of main AM fungal genus in the root and soil samples. Genus and OTUs with average relative abundances $>1 \%$ were shown in at least one treatment. Values in the bar plot are expressed as mean \pm standard error. Asterisks indicate significant difference between treatments based on Tukey's test $(P<0.05)$ 

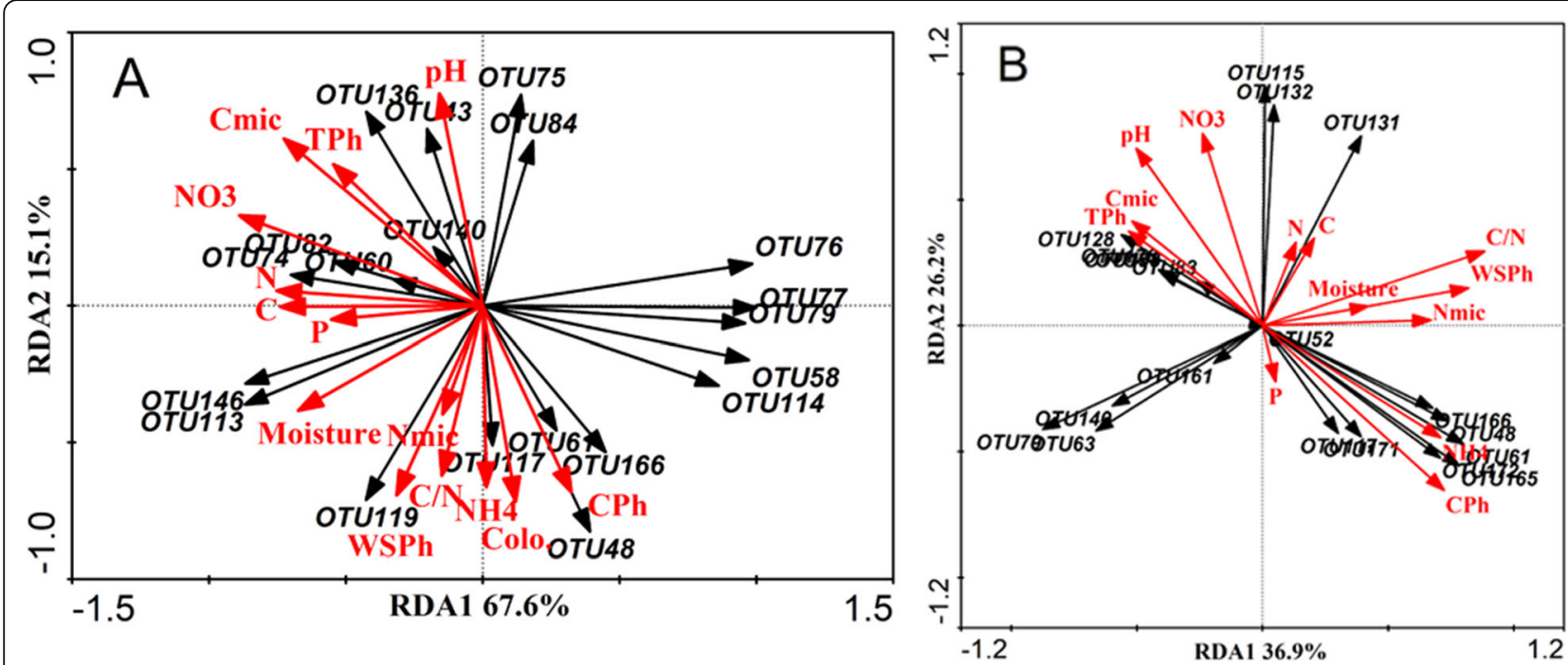

Fig. 7 Ordination plots of the results from the redundancy analysis (RDA) to identify the relationships among the AM fungal taxa (Black arrows) and the soil characteristics (Red arrows). The top 20 most abundant classified AM fungal OTUs (97\% sequence similarity) in the root (A) and soil (B) samples. $C_{\text {mic }}$ : soil microbial biomass carbon. $\mathrm{N}_{\text {mic }}$ : soil microbial biomass nitrogen. TPh: soil total phenol. CPh: soil complex phenol. WSPh: soil water-soluble phenol. $\mathrm{NO}_{3}: \mathrm{NO}_{3}{ }^{-}-\mathrm{N}$. $\mathrm{NH}_{4}: \mathrm{NH}_{4}{ }^{+} \mathrm{N}$

mixed plantation than in the pure plantation may have been attributable to the lower "carrying capacity" in the mixed plantation, i.e., the lower number of walnut roots. In mixture, larch roots have greater plasticity in traits related to resource uptake than walnut roots [37]. In addition, larch root exudates alleviate the autotoxic effect caused by juglone, which is secreted by Manchurian walnut in mixed plantings. Our previous studies have found that larch root exudates promote changes in the

Table 2 Mantel analysis on the relationship between the relative abundance of OTUs and soil or plant variables

\begin{tabular}{|c|c|c|c|c|}
\hline \multirow{2}{*}{$\begin{array}{l}\text { Environmental } \\
\text { variables }\end{array}$} & \multicolumn{2}{|l|}{ Root } & \multicolumn{2}{|l|}{ Soil } \\
\hline & $R^{2}$ & $P$ & $R^{2}$ & $P$ \\
\hline $\mathrm{pH}$ & 0.647 & 0.213 & 0.695 & 0.158 \\
\hline Moisture (\%) & 0.61 & 0.257 & 0.178 & 0.743 \\
\hline$C\left(\mathrm{~g} \cdot \mathrm{kg}^{-1}\right)$ & 0.543 & 0.29 & 0.148 & 0.788 \\
\hline$N\left(g \cdot \mathrm{kg}^{-1}\right)$ & 0.565 & 0.254 & 0.116 & 0.821 \\
\hline$P\left(g \cdot \mathrm{kg}^{-1}\right)$ & 0.311 & 0.594 & 0.047 & 0.922 \\
\hline $\mathrm{C} / \mathrm{N}$ & 0.386 & 0.472 & 0.864 & $0.032^{*}$ \\
\hline$C_{\text {mic }}\left(\mathrm{mg} \cdot \mathrm{kg}^{-1}\right)$ & 0.881 & $0.044^{*}$ & 0.455 & 0.415 \\
\hline $\mathrm{N}_{\text {mic }}\left(\mathrm{mg} \cdot \mathrm{kg}^{-1}\right)$ & 0.170 & 0.749 & 0.439 & 0.411 \\
\hline $\mathrm{NH}_{4}{ }^{+}-\mathrm{N}\left(\mathrm{mg} \cdot \mathrm{kg}^{-1}\right)$ & 0.454 & 0.394 & 0.688 & 0.165 \\
\hline $\mathrm{NO}_{3}{ }^{-}-\mathrm{N}\left(\mathrm{mg} \cdot \mathrm{kg}^{-1}\right)$ & 0.906 & $0.029 *$ & 0.656 & 0.208 \\
\hline TPh $\left(\mathrm{mg} \cdot \mathrm{kg}^{-1}\right)$ & 0.542 & 0.336 & 0.442 & 0.419 \\
\hline $\mathrm{CPh}\left(\mathrm{mg} \cdot \mathrm{kg}^{-1}\right)$ & 0.603 & 0.257 & 0.944 & $0.019 *$ \\
\hline WSPh (mg.kg-1) & 0.601 & 0.233 & 0.676 & 0.179 \\
\hline Colonization (\%) & 0.521 & 0.306 & - & - \\
\hline
\end{tabular}

$C_{\text {mic }}$ soil microbial biomass carbon, $N_{\text {mic }}$ soil microbial biomass nitrogen, TPh soil total phenol, CPh soil complex phenol, WSPh soil water-souble phenol soil microbial communities of Manchurian walnut and increase soil invertase and urease activities [38]. Salahuddin et al. [37] indicated that the ratio of root tip tissue in Manchurian walnut significantly increased after larch was introduced, but the mycorrhizal infection rate was decreased. Achatz et al. [39] found that mycorrhizal mycelia promoted the migration and transport of juglone secreted by plant roots and that mycorrhizal mycelia enhanced interspecific interactions through the study of species of the genus Juglans (Juglandaceae). Mummey and Rillig [20] found that spotted knapweed, an invasive plant, could significantly change the AM fungal community in the invasion site.

The AM fungal community composition and abundance were obviously different between the pure and mixed plantations (Fig. 2 and Fig. 6), and there were more OTUs in the soil of the mixed plantation (Fig. 5). The reasons may be as follows: (1) Compared with the pure plantation, the mixed plantation had more advantages in terms of litter quantity and quality, soil nutrients and stand structure. The consequent changes in the soil microenvironment led to variations in the AM fungal community and (2) larch affects the root system of Manchurian walnut when they are planted in mixture, which reshapes the mycorrhizal network. Chen et al. [40] found that abiotic factors (soil moisture content, nitrate and soil enzymes, etc.) had a greater impact on the soil AM fungal community when Robinia pseudoacacia was mixed with Platycladus orientalis. The growth of some plants may change the soil quality or other abiotic characteristics, which may lead to changes in rhizosphere AM fungal communities [41]. 


\section{Comparison of AM fungal communities in root and soil samples}

Our study found that the AM fungal community in the root system of Manchurian walnut was significantly different from that in the rhizosphere soil, which is consistent with previous results from temperate steppe [42], temperate farmland [43] and Mediterranean shrub communities [44]. This is because plants select AM fungi to varying degrees based on their own nutritional requirements in different growth and development stages, and the selection inevitably leads to differences in the relative abundance, species and quantity of AM fungi in soil and roots. In addition, there are substantial differences between the environmental conditions of AM fungi in plant roots and those in soil. The living environment of AM fungi in roots is mainly regulated by the physiological activities of individual plants, while AM fungi in soil are mainly affected by external environmental conditions.

Many scholars believe that the AM fungal community in soil represents a species pool and that plants can freely recruit certain species, suggesting that the AM fungal richness in soil is higher than that in the roots [45-48]. However, some scholars have found that the abundance of AM fungi in roots and soil is the same [49-51] or that AM fungi are more abundant in the root system than in the soil $[52,53]$. In this study, the amount of OTUs in roots was higher than that in soil samples (in both the pure and mixed plantations), and a large proportion of AM fungi were detected in roots. There are many potential methodological and biological explanations for the differences in the AM fungal community, especially for the low number of OTUs detected in soil. First, the biomass of AM fungi in soil is an order of magnitude lower than that in roots [54]. Therefore, the concentration of soil AM fungal DNA is relatively low. The DNA extracted from the roots is an accurate measure of the root subsample, while the very small mass extracted from the soils likely excludes numerous species that were present in the composite soil sample from which the subsample was removed [55].

Second, there are differences in the distribution of AM fungi of different taxa between the root (intraradical) and soil (extraradical) samples [56]. Glomeraceae spend fewer resources on their external structures than on their internal structures [57]. In this study, Glomus was more abundant in the roots than in the soil, which was consistent with previous research results. Some studies have found that Gigasporaceae and Acaulosporaceae many more external hyphae than internal structures. In this study, Diversisporaceae and Gigasporaceae were mainly found in soil, with low sequence numbers in the root system; this is consistent with earlier findings that Diversisporaceae and Gigasporaceae are poor root colonizers [42, 53, 57]. Paraglomeraceae was mainly found in soil samples, with only a few sequences in the roots, which is consistent with previous studies $[42,53]$.

\section{Conclusions}

Our study showed that long-term (almost 30 years) mixed management had little effect on the AM fungal community in the roots of Juglans mandshurica and significantly changed the community composition, but not the diversity, of AM fungi in the soils. Samples from the roots in the pure plantation had the highest number of unique OTUs. The core species composition of AM fungal communities was very similar and conservative between the pure and mixed plantations. In the future, the combination of root traits and mycorrhizal symbiosis should be considered to comprehensively evaluate the mechanisms of nutrient absorption and utilization by mixed tree species to lay a foundation for sustainable plantation management.

\section{Methods}

\section{Study area and sample design}

The study site was located at the Maoershan Forest $\mathrm{Re}$ search Station $\left(127^{\circ} 30^{\prime}-127^{\circ} 34^{\prime} \mathrm{E}, 45^{\circ} 21^{\prime}-45^{\circ} 25^{\prime} \mathrm{N}\right)$ of Northeast Forestry University, Heilongjiang Province, China. This area is characterized by a continental monsoon climate with a windy spring, a warm and humid summer, and a dry and cold winter. The mean annual temperature is $2.8^{\circ} \mathrm{C}$, with the minimum temperature in January $\left(-40.9^{\circ} \mathrm{C}\right)$ and the maximum temperature in July $\left(34.2^{\circ} \mathrm{C}\right)$. The frost-free period fluctuates between 120 and 140 days. The annual precipitation ranges from 600 to $800 \mathrm{~mm}$. Soils are Hap-Boric Luvisols [58] with high organic matter content and well-developed horizons and are well drained.

In spring 1987, one-year-old seedlings of Juglans mandshurica and Larix gmelinii were obtained from the Maoershan Forest Farm and transplanted to the experimental station to establish the monoculture (Juglans mandshurica, JM) and mixed (Juglans mandshurica $\times$ Larix gmelinii, $\mathrm{J} \times \mathrm{L}$ ) plantations of Manchurian walnut (each pure or mixed forest of $\sim 0.5 \mathrm{ha}$ ). The seedlings were planted in a $1.5 \mathrm{~m} \times 1.5 \mathrm{~m}$ grid in each plantation and mixed in rows (three rows of $\mathrm{JM} \times$ five rows of larch) in the mixed plantation. The plantations both have similar site conditions and an average gradient of $7^{\circ}$. Detailed tree growth information for each plantation is shown in Table S1. Voucher specimens of J. mandshurica and L. gmelinii were not deposited in this study since they are the most common trees in Northeast China. 


\section{Sample collection}

In April 2016, three random sampling plots $(20 \mathrm{~m} \times 30$ $\mathrm{m} 0.06 \mathrm{ha}$ ) were selected from the pure and mixed plantations described above and were identified to serve as replicates. The distance between plots ranged from 350 $\mathrm{m}$ to $700 \mathrm{~m}$. Rhizosphere soil and plant root samples were collected in July 2016. In each of these experimental plots, root samples were collected from nine individuals of Juglans mandshurica and mixed to form a composite sample from each plot. The rhizosphere soils were sampled in the $0-10 \mathrm{~cm}$ soil layer adjacent to the roots, and the sample soil was brushed off of the plant root systems. The soil and root samples were packed in an ice box and transported to the laboratory. Soil samples were sieved ( $1 \mathrm{~mm}$ mesh) to remove roots and debris, and subsamples were stored at $-80{ }^{\circ} \mathrm{C}$ for DNA extraction. The first three root orders of the roots of Juglans mandshurica are infected by mycorrhiza [59]. Root samples were washed using distilled water to remove soil particles and were stored at $-80{ }^{\circ} \mathrm{C}$ for DNA extraction.

\section{DNA extraction and PCR amplification}

Microbial DNA was extracted from root and soil samples using the E.Z.N.A. ${ }^{\circ}$ soil DNA Kit (Omega Biotek, Norcross, GA, U.S.) according to the manufacturer's protocols. The final DNA concentration and purification were determined by a NanoDrop 2000 UV-vis spectrophotometer (Thermo Scientific, Wilmington, USA), and DNA quality was checked by $1 \%$ agarose gel electrophoresis. The fungal $18 \mathrm{~S}$ rRNA genes were amplified by a nested PCR. According to the study of Lumini et al. 2010 [60], AML1 (5'-ATCAACTTTCGATGGTAGGAT AGA-3') and AML2 (5'-GAACCCAAACA CTTTGG TTTCC-3'), where the barcode is an eight-base sequence unique to each sample, were used in the first round of PCR, and AMV4-5NF (5'-AAGCTCGTAG TTGAATTTCG-3') and AMDGR (5'-CCCAACTATC CCTATTAATCAT-3') were used in the second round of PCR with a thermocycler PCR system (GeneAmp 9700, ABI, USA). The two rounds of PCR yielded amplicons of approximately $800 \mathrm{bp}$ and $300 \mathrm{bp}$, respectively. PCRs were performed in triplicate in a $20 \mu \mathrm{L}$ mixture containing $4 \mu \mathrm{L}$ of $5 \times$ FastPfu Buffer, $2 \mu \mathrm{L}$ of $2.5 \mathrm{mM}$ dNTPs, $0.8 \mu \mathrm{L}$ of each primer $(5 \mu \mathrm{M}), 0.4 \mu \mathrm{L}$ of FastPfu Polymerase and $10 \mathrm{ng}$ of template DNA. The PCRs were conducted using the following program: 3 min of denaturation at $95^{\circ} \mathrm{C}, 30$ cycles of $30 \mathrm{~s}$ at $95^{\circ} \mathrm{C}$, $30 \mathrm{~s}$ for annealing at $55^{\circ} \mathrm{C}$, and $45 \mathrm{~s}$ for elongation at $72{ }^{\circ} \mathrm{C}$, and a final extension at $72{ }^{\circ} \mathrm{C}$ for $10 \mathrm{~min}$. The procedure for the second round of PCRs was the same as that for the first round, except for the cycle number, which was 35 [61].

\section{Illumina MiSeq sequencing}

The resulting PCR products were extracted from a $2 \%$ agarose gel, further purified using the AxyPrep DNA Gel Extraction Kit (Axygen Biosciences, Union City, CA, USA) and quantified using QuantiFluor ${ }^{\text {Tw }}$-ST (Promega, USA) according to the manufacturer's protocol. Purified amplicons were pooled in equimolar amounts and paired-end sequenced $(2 \times 250)$ on an Illumina MiSeq platform (Illumina, San Diego, USA) according to the standard protocols by Majorbio Bio-Pharm Technology Co., Ltd. (Shanghai, China). The raw reads were deposited into the NCBI Sequence Read Archive (SRA) database (Accession Number: SRP227587).

\section{Processing of sequencing data}

Raw fastq files were demultiplexed, quality filtered by Trimmomatic and merged by FLASH with the following criteria [62]: (i) The reads were truncated at any site receiving an average quality score $<20$ over a $50 \mathrm{bp}$ sliding window. (ii) Primers were exactly matched, allowing two nucleotide mismatches, and reads containing ambiguous bases were removed. (iii) Sequences whose overlap was longer than $10 \mathrm{bp}$ were merged according to their overlap sequence.

Operational taxonomic units (OTUs) were clustered with a $97 \%$ similarity cutoff using UPARSE (version 7.1 http://drive5.com/uparse/) [63], and chimeric sequences were identified and removed using UCHIME. The taxonomy of each 18S rRNA gene sequence was analyzed by BLAST against the MaarjAM database with a confidence threshold of $70 \%$.

\section{Soil physicochemical analyses}

Total carbon $(\mathrm{C})$ and total nitrogen $(\mathrm{N})$ were measured by a Macro Elemental Analyzer (vario MACRO, Elementar Co., Germany), and total phosphorus (P) was determined colorimetrically with a UV spectrophotometer (TU-1901, Puxi Ltd., Beijing, China) after wet digestion with $\mathrm{HClO}_{4}-\mathrm{H}_{2} \mathrm{SO}_{4}$. Soil $\mathrm{pH}$ was measured using a $\mathrm{pH}$ meter (MT-5000, Shanghai). Soil nitrate-N $\left(\mathrm{NO}_{3}{ }^{-}-\mathrm{N}\right)$ and ammonium- $\mathrm{N}\left(\mathrm{NH}_{4}{ }^{+}-\mathrm{N}\right)$ were extracted in $2 \mathrm{M} \mathrm{KCl}$ and measured using a continuous-flow ion autoanalyzer (Scalar SANplus segmented flow analyzer, The Netherlands). The soil total phenol content was measured by the ultraviolet spectrophotometer method [64]. The Folin reagent colorimetric method was used to determine soil water-soluble phenol and complex phenol content [64]. Soil microbial biomass carbon (MBC) and nitrogen $(\mathrm{MBN})$ were measured using a chloroform fumigation extraction method [65]. The mycorrhizal colonization rate of fine roots was determined according to the method of Guo [59]. 


\section{Statistical analysis}

For the Illumina MiSeq sequencing data, the alpha diversity indices (number of observed OTUs, Chao1, ACE, Faith's PD, Shannon and Simpson diversity indices) were generated using QIIME [66]. For the beta diversity analysis, Bray-Curtis distances were calculated, and principal coordinate analysis (PCoA) was conducted to visualize the community similarity using the 'vegan' package in ' $R$ ' (Version 3.6.1) [67]. Analysis of similarities (ANOSIM) and permutation multivariate analysis of variance (PERMANOVA) were carried out to test the differences among microbial communities with the Bray-Curtis distances and 999 permutations. Heat map analysis was used to compare the relative abundances of the top 50 most abundant classified AM fungal genera among treatments with the 'pheatmap' package in ' $R$ ' (Version 3.6.1). The shared and unique OTUs among treatments were counted, and their distributions are shown in a Venn diagram created with the 'VennDiagram' package in ' $R$ ' (Version 3.6.1). Differences in the relative abundance of microbial taxa between treatments were analyzed using Welch's $t$ test and Tukey's honestly significant difference (HSD) test with Bonferroni correction in 'STAMP' [68]. The differences were considered statistically significant if $P<0.05$. Redundancy analysis (RDA) was used to identify the soil properties that predicted the variations in the AM fungal communities. The Mantel test with a Monte Carlo simulation with 999 randomizations was used to assess the relationships between the Euclidean distance of the AM fungal community and the soil characteristics. RDA and Mantel test analyses were performed with the rda function in the 'vegan' package and the mantel.rtest function in the 'ade4' package in ' $R$ ' (Version 3.6.1), respectively.

\section{Supplementary information}

Supplementary information accompanies this paper at https://doi.org/10. 1186/s12866-020-01987-1.

Additional file 1: Figure S1. The Rarefaction curves of the number of operational taxonomic units (OTUs) for AM fungal communities. Figure S2. Relative abundances of main AM fungal genus ( $A, C, E, G)$ and OTUs $(B, D, F, H)$ in the root and soil samples. Table S1. Summary of stand and soil characteristics of three plantations used in this study: pure plantation of Juglans mandshurica and mixed plantation of Juglans mandshurica $x$ Larix gmelinii in NE China. Table S2. Relative abundances (\%) of the top 50 most abundant classified arbuscular mycorrhizal fungal OTUs in the root and soil samples. Table S3. Dissimilarity analysis of AM fungal communities with permutation multivariate analysis of variance (PERM ANOVA). Table S4. Sequence of OTUs all shared to the root and soil samples in pure and mixed plantation. Table S5. Sequence of OTUs all unique to the root samples in pure plantation.

\section{Abbreviations}

AM: Arbuscular mycorrhiza; OTUs: Operational Taxonomic Units; $\mathrm{C}_{\text {mic }}$ : Soil microbial biomass carbon; $\mathrm{N}_{\text {mic }}$ : Soil microbial biomass nitrogen; TPh: Soil total phenol; CPh: Soil complex phenol; WSPh: Soil water-souble phenol; Soil_P: Soil sample in pure plantation; Soil_M: Soil sample in mixed plantation; Root_P: Root sample in pure plantation; Root_M: Root sample in mixed plantation

\section{Acknowledgements}

We thank the assistant from Maoershan Forest Research Station in the field works.

\section{Authors' contributions}

$L J, Y Y$, and $L Y$ designed the work. $L J, N Y$ and $Y Z$ performed the fieldwork, $L J$ wrote the manuscript. $L$ and DZ conducted molecular experiments and analyzed the data. All authors have read and approved the manuscript.

\section{Funding}

This work was financially supported by the Fundamental Research Funds for the Central Universities (2572019AA07), the National Key Research and Development Program of China (2017YFD0601204), the Fundamental Research Funds for the Central Universities (2572019CP16), and the Heilongjiang Touyan Innovation Team Program (Technology Development Team for Highly efficient Silviculture of Forest Resources). The funding agencies had no role in the study design, sample collection, data collection and analysis, and manuscript preparation.

\section{Availability of data and materials}

All datasets are presented in the main text and the additional file. The raw sequence data on $18 \mathrm{~S}$ rRNA gene amplicons have been submitted to the NCBI Sequence Read Archive (SRA) database (Accession Number: SRP227587). The dataset analyzed during the current study is available from the corresponding author on reasonable request.

Ethics approval and consent to participate

This study and the submission have been approved by the research ethics committee at Northeast Forestry University.

Consent for publication

Not applicable.

\section{Competing interests}

The authors declare that they have no competing interests.

\section{Author details}

${ }^{1}$ Key Laboratory of Sustainable Forest Ecosystem Management-Ministry of Education, School of Forestry, Northeast Forestry University, Harbin 150040, P. R. China. ${ }^{2}$ Jilin Academy of Forestry, Changchun 130033, P.R. China. ${ }^{3}$ ZEHO Waterfront Ecological Environment Management Co., Ltd, Beijing 100084, P. R. China.

Received: 22 June 2020 Accepted: 25 September 2020

Published online: 12 October 2020

\section{References}

1. Smith SE, Read DJ. Mycorrhizal symbiosis: academic press; 2010.

2. Smith SE, Smith FA, Jakobsen I. Mycorrhizal fungi can dominate phosphate supply to plants irrespective of growth responses. Plant Physiol. 2003;133: $16-20$.

3. Hodge A, Fitter AH. Substantial nitrogen acquisition by arbuscular mycorrhizal fungi from organic material has implications for $\mathrm{N}$ cycling. Proc Natl Acad Sci. 2010;107:13754-9.

4. Smith SE, Smith FA. Roles of arbuscular mycorrhizas in plant nutrition and growth: new paradigms from cellular to ecosystem scales. Annu Rev Plant Biol. 2011;62:227-50.

5. Borowicz VA. Do arbuscular mycorrhizal fungi alter plant-pathogen relations? Ecology. 2001;82:3057-68.

6. Aroca R, Porcel R, Ruiz-Lozano JM. How does arbuscular mycorrhizal symbiosis regulate root hydraulic properties and plasma membrane aquaporins in Phaseolus vulgaris under drought, cold or salinity stresses? New Phytol. 2007;173:808-16.

7. Marler MJ, Zabinski CA, Callaway RM. Mycorrhizae indirectly enhance competitive effects of an invasive forb on a native bunchgrass. Ecology. 1999:80:1180-6.

8. Wilson GW, Rice CW, Rillig MC, Springer A, Hartnett DC. Soil aggregation and carbon sequestration are tightly correlated with the abundance of 
arbuscular mycorrhizal fungi: results from long-term field experiments. Eco Lett. 2009;12:452-61.

9. Eom A-H, Hartnett DC, Wilson GW. Host plant species effects on arbuscular mycorrhizal fungal communities in tallgrass prairie. Oecologia. 2000;122: 435-44.

10. Vandenkoornhuyse P, Husband R, Daniell T, Watson I, Duck J, Fitter A, et al. Arbuscular mycorrhizal community composition associated with two plant species in a grassland ecosystem. Mol Ecol. 2002;11:1555-64.

11. Wyatt GA, Kiers ET, Gardner A, West SA. A biological market analysis of the plant-mycorrhizal symbiosis. Evolution. 2014;68:2603-18.

12. Hausmann NT, Hawkes CV. Plant neighborhood control of arbuscular mycorrhizal community composition. New Phytol. 2009;183:1188-200.

13. Chagnon P-L, Bradley RL, Maherali H, Klironomos JN. A trait-based framework to understand life history of mycorrhizal fungi. Trends Plant Sci. 2013:18:484-91.

14. Varela-Cervero S, López-García Á, Barea JM, Azcón-Aguilar C. Differences in the composition of arbuscular mycorrhizal fungal communities promoted by different propagule forms from a Mediterranean shrubland. Mycorrhiza. 2016;26:489-96.

15. Kernaghan G. Mycorrhizal diversity: cause and effect? Pedobiologia. 2005;49: 511-20.

16. de Oliveira FR, Buscardo E, Nagy L, dos Santos Maciel AB, Carrenho R, Luizão RC. Arbuscular mycorrhizal fungal communities along a pedo-hydrological gradient in a central Amazonian terra firme forest. Mycorrhiza. 2014;24:21-32.

17. Pallardy SG. Physiology of woody plants: academic press; 2010.

18. Stevens BM, Propster JR, Öpik M, Wilson GW, Alloway SL, Mayemba E, et al. Arbuscular mycorrhizal fungi in roots and soil respond differently to biotic and abiotic factors in the Serengeti. Mycorrhiza. 2020;30:79-95.

19. Simard SW, Durall DM. Mycorrhizal networks: a review of their extent, function, and importance. Can J Bot. 2004;82:1140-65.

20. Mummey DL, Rillig MC. The invasive plant species Centaurea maculosa alters arbuscular mycorrhizal fungal communities in the field. Plant Soil. 2006;288:81-90.

21. Morris EK, Buscot F, Herbst C, Meiners T, Obermaier E, Wäschke NW, et al. Land use and host neighbor identity effects on arbuscular mycorrhizal fungal community composition in focal plant rhizosphere. Biodivers Conserv. 2013;22:2193-205.

22. Lang AC, von Oheimb G, Scherer-Lorenzen M, Yang B, Trogisch S, Bruelheide $\mathrm{H}$, et al. Mixed afforestation of young subtropical trees promotes nitrogen acquisition and retention. J Appl Ecol. 2014;51:224-33.

23. Yang $\mathrm{K}$, Shi W, Zhu JJ. The impact of secondary forests conversion into larch plantations on soil chemical and microbiological properties. Plant Soil. 2013; 368:535-46.

24. Zhang J-T. Succession analysis of plant communities in abandoned croplands in the eastern loess plateau of China. J Arid Environ. 2005;63:458-74.

25. Montagnini F. Accumulation in above-ground biomass and soil storage of mineral nutrients in pure and mixed plantations in a humid tropical lowland. For Ecol Manag. 2000;134:257-70.

26. Bauhus J, Van Winden AP, Nicotra AB. Aboveground interactions and productivity in mixed-species plantations of Acacia mearnsii and Eucalyptus globulus. Can J For Res. 2004;34:686-94.

27. Forrester Dl, Bauhus J, Cowie AL. On the success and failure of mixedspecies tree plantations: lessons learned from a model system of Eucalyptus globulus and Acacia mearnsii. For Ecol Manag. 2005;209:147-55.

28. Lamb D. Natural regeneration and secondary forests. In: Regreening the Bare Hills. Dordrecht: Springer; 2011. p. 157-209.

29. Carnevale NJ, Montagnini F. Facilitating regeneration of secondary forests with the use of mixed and pure plantations of indigenous tree species. For Ecol Manag. 2002;163:217-27.

30. Kelty MJ. The role of species mixtures in plantation forestry. For Ecol Manag. 2006;233:195-204

31. Mao Q, Watanabe M, Koike T. Growth characteristics of two promising tree species for afforestation, birch and larch in the northeastern part of Asia. Eurasian J Forest Res. 2010;13:69-76.

32. Son Y, Lee IK, Ryu SR. Nitrogen and phosphorus dynamics in foliage and twig of pitch pine and Japanese larch plantations in relation to fertilization. J Plant Nutr. 2000;23:697-710

33. Shi FY, Chen XQ, NQ C. Study on the artificial mixed forest of Juglans mandshurica and Larix olgensis. J Northeast Forest Univ. 1991;19:32-43.

34. Senés-Guerrero C, Schüßler A. A conserved arbuscular mycorrhizal fungal core-species community colonizes potato roots in the Andes. Fungal Divers. 2016;77:317-33.
35. Van der Heijden MG, Klironomos JN, Ursic M, Moutoglis P, Streitwolf-Enge $\mathrm{R}$, Boller T, et al. Mycorrhizal fungal diversity determines plant biodiversity, ecosystem variability and productivity. Nature. 1998;396:69.

36. Kiers ET, Lovelock CE, Krueger EL, Herre EA. Differential effects of tropical arbuscular mycorrhizal fungal inocula on root colonization and tree seedling growth: implications for tropical forest diversity. Ecol Lett. 2000;3: 106-13.

37. Salahuddin RB, Razaq M, Lixue Y, Li J, Khan F, Jie Z. Root order-based traits of Manchurian walnut \& larch and their plasticity under interspecific competition. Sci Rep. 2018:8:9815.

38. Yang L, Wang P, Kong C. Effect of larch (Larix gmelini Rupr.) root exudates on Manchurian walnut (Juglans mandshurica maxim.) growth and soil juglone in a mixed-species plantation. Plant Soil. 2010;329:249-58.

39. Achatz M, Morris EK, Müller F, Hilker M, Rillig MC, Field K. Soil hyphamediated movement of allelochemicals: arbuscular mycorrhizae extend the bioactive zone of juglone. Funct Ecol. 2014;28:1020-9.

40. Chen X, Tang M, Zhang X, Hamel C, Liu S, Huo Y, et al. Effects of plant neighborhood on arbuscular mycorrhizal fungal attributes in afforested zones. For Ecol Manag. 2018;422:253-62.

41. Zheng Y, Chen L, Luo C-Y, Zhang Z-H, Wang S-P, Guo L-D. Plant identity exerts stronger effect than fertilization on soil arbuscular mycorrhizal fungi in a sown pasture. Microb Ecol. 2016;72:647-58.

42. Hempel S, Renker C, Buscot F. Differences in the species composition of arbuscular mycorrhizal fungi in spore, root and soil communities in a grassland ecosystem. Environ Microbiol. 2007;9:1930-8.

43. Mirás-Avalos JM, Antunes PM, Koch A, Khosla K, Klironomos JN, Dunfield KE. The influence of tillage on the structure of rhizosphere and root-associated arbuscular mycorrhizal fungal communities. Pedobiologia. 2011;54:235-41.

44. Torrecillas E, del Mar AM, Roldán A. Differences in the AMF diversity in soil and roots between two annual and perennial gramineous plants COoccurring in a Mediterranean, semiarid degraded area. Plant Soil. 2012;354: 97-106.

45. Balestrini R, Magurno F, Walker C, Lumini E, Bianciotto V. Cohorts of arbuscular mycorrhizal fungi (AMF) in Vitis vinifera, a typical Mediterranean fruit crop. Environ Microbiol Rep. 2010;2:594-604.

46. Bainard LD, Koch AM, Gordon AM, Newmaster SG, Thevathasan NV, Klironomos JN. Influence of trees on the spatial structure of arbuscular mycorrhizal communities in a temperate tree-based intercropping system. Agric Ecosyst Environ. 2011;144:13-20.

47. Torrecillas E, Alguacil M, Roldán A. Host preferences of arbuscular mycorrhizal fungi colonizing annual herbaceous plant species in semiarid Mediterranean prairies. Appl Environ Microbiol. 2012;78:6180-6.

48. Hassan SED, Boon E, ST-ARNAUD M, Hijri M. Molecular biodiversity of arbuscular mycorrhizal fungi in trace metal-polluted soils. Mol Ecol. 2011;20:3469-83.

49. Hannula S, De Boer W, Van Veen J. In situ dynamics of soil fungal communities under different genotypes of potato, including a genetically modified cultivar. Soil Biol Biochem. 2010;42:2211-23.

50. Verbruggen E, Kuramae EE, Hillekens R, de Hollander M, Kiers ET, Röling WF, et al. Testing potential effects of maize expressing the bacillus thuringiensis Cry $1 \mathrm{Ab}$ endotoxin (Bt maize) on mycorrhizal fungal communities via DNAand RNA-based pyrosequencing and molecular fingerprinting. Appl Environ Microbiol. 2012;78:7384-92.

51. Busby RR, Stromberger ME, Rodriguez G, Gebhart DL, Paschke MW. Arbuscular mycorrhizal fungal community differs between a coexisting native shrub and introduced annual grass. Mycorrhiza. 2013;23:129-41.

52. Pivato B, Mazurier S, Lemanceau P, Siblot S, Berta G, Mougel C, et al. Medicago species affect the community composition of arbuscular mycorrhizal fungi associated with roots. New Phytol. 2007;176:197-210.

53. Varela-Cervero S, Vasar M, Davison J, Barea JM, Öpik M, Azcón-Aguilar C. The composition of arbuscular mycorrhizal fungal communities differs among the roots, spores and extraradical mycelia associated with five Mediterranean plant species. Environ Microbiol. 2015;17:2882-95.

54. Olsson PA, Rahm J, Aliasgharzad N. Carbon dynamics in mycorrhizal symbioses is linked to carbon costs and phosphorus benefits. FEMS Microbiol Ecol. 2010;72:125-31.

55. Busby RR, Stromberger ME, Rodriguez G. Gebhart, D. L., \& Paschke, M. W. Arbuscular mycorrhizal fungal community differs between a coexisting native shrub and introduced annual grass [J]. Mycorrhiza. 2013;23(2):129-41.

56. Hart MM, Reader RJ, Klironomos JN. Life-history strategies of arbuscular mycorrhizal fungi in relation to their successional dynamics. Mycologia. 2001;93:1186-94. 
57. Hart MM, Reader RJ. Taxonomic basis for variation in the colonization strategy of arbuscular mycorrhizal fungi. New Phytol. 2002;153:335-44

58. Gong ZT, Chen ZC, Luo GB, Zhang GL, Zhao WJ. Chinese soil system classification reference. Soil. 1999;22:57-63 (in Chinese).

59. Guo D, Xia M, Wei X, Chang W, Liu Y, Wang Z. Anatomical traits associated with absorption and mycorrhizal colonization are linked to root branch order in twenty-three Chinese temperate tree species. New Phytol. 2008; 180:673-83.

60. Lumini E, Orgiazzi A, Borriello R, Bonfante P, Bianciotto V. Disclosing arbuscular mycorrhizal fungal biodiversity in soil through a land-use gradient using a pyrosequencing approach. Environ Microbiol. 2010;12: 2165-79.

61. Zeng $H$, Zhong $W$, Tan F, Shu Y, Feng Y, Wang J. The influence of Bt maize cultivation on communities of Arbuscular Mycorrhizal fungi revealed by MiSeq sequencing. Front Microbiol. 2019;9:3275.

62. Caporaso JG, Kuczynski J, Stombaugh J, Bittinger K, Bushman FD, Costello EK, et al. QIIME allows analysis of high-throughput community sequencing data [J]. Nat Methods. 2010;7:335-6.

63. Edgar RC. UPARSE: highly accurate OTU sequences from microbial amplicon reads [J]. Nat Methods. 2013;10:996-8.

64. Kuiters AT, Sarink HM. Leaching of phenolic compounds from leaf and needle litter of several deciduous and coniferous trees. Soil Biol Biochem. 1986;18:475-80

65. Brookes P, Landman A, Pruden G, Jenkinson D. Chloroform fumigation and the release of soil nitrogen: a rapid direct extraction method to measure microbial biomass nitrogen in soil. Soil Biol Biochem. 1985:17:837-42.

66. Caporaso JG, Kuczynski J, Stombaugh J, Bittinger K, Bushman FD, Costello EK, et al. QIIME allows analysis of high-throughput community sequencing data. Nat Methods. 2010;7:335.

67. R Development Core Team R. R: a language and environment for statistica computing. In: R foundation for statistical computing Vienna, Austria; 2011.

68. Parks DH, Tyson GW, Hugenholtz P, Beiko RG. STAMP: statistical analysis of taxonomic and functional profiles. Bioinformatics. 2014:30:3123-4.

\section{Publisher's Note}

Springer Nature remains neutral with regard to jurisdictional claims in published maps and institutional affiliations.

Ready to submit your research? Choose BMC and benefit from:

- fast, convenient online submission

- thorough peer review by experienced researchers in your field

- rapid publication on acceptance

- support for research data, including large and complex data types

- gold Open Access which fosters wider collaboration and increased citations

- maximum visibility for your research: over $100 \mathrm{M}$ website views per year

At $\mathrm{BMC}$, research is always in progress.

Learn more biomedcentral.com/submissions 